\title{
Linguistic ethnography and the study of welfare institutions as a flow of social practices: the case of residential child care institutions as paradoxical institutions ${ }^{*}$
}

\author{
MANUEL PALOMARES and DAVID POVEDA
}

\section{Abstract}

In this article we review ways of understanding how social and welfare institutions achieve their goals and produce their products, whether these are expected or not. We analyze mainstream approaches to study these institutions in Spain and in other parts of Europe. From this review, we argue in favor of an approach focused on the role of social practices as constitutive elements of institutional life and products. Our proposal focuses on one type of institution, residential child care institutions ( RCCIs), to highlight how traditional limits between formally designed activities and informal practices may be problematized. The data comes from a brief linguistic ethnography, conducted in central Spain, in two RCCIs that focused on children's everyday social practices in the institution. We argue that RCCIs may be characterized as "paradoxical institutions" due to what we call "paradoxical practices," prototypical of these institutions. As part of this argument, we analyze and discuss the trajectory of a paradoxical practice by paying attention to the product it creates and develop a model to understand institutional functioning. Finally, we discuss how linguistic ethnography provides a valuable alternative to scrutinize the work of residential child care institutions and the role they play in children's socialization.

Keywords: social work; child protection and welfare; residential child care institutions; linguistic ethnography; socialization; social practice.

\section{Introduction}

\subsection{Three ways of studying social and welfare institutions}

Different institutions have been created throughout history in order to offer "social or welfare services" such as hospitals, orphanages, or schools. 
As institutions, they have tried to improve the services they offered and, especially in recent decades, research has played a key role in these efforts. In Spain, as elsewhere, public policy research has drawn mainly on three alternative approaches. To organize the contrasts between these approaches we will draw on current neoliberal policy and managerial terminology to understand institutional procedures. These terms are not necessarily embraced by the models we discuss, nor does their use imply we espouse neoliberal public policy but, for lack of better terms, they provide accessible metaphors to describe the various elements involved in institutional processes. We will talk about "products" (i.e., health, care, or education), "clients" (i.e., people who receive institutional attention, such as patients, children under protection, or students), "agents" (i.e., the treatment, programs, therapies, persons who are considered responsible for constructing the product), and "institutions" (i.e., organizations such as hospitals, residential institutions, or schools). We will also talk about "institutional life" as something different from "institution" (i.e., as the experiences lived by clients while under the responsibility of an institution and its professionals).

The first approach reproduces classic process-product research in education and holds that there are features "inside" clients that may be discovered (e.g., diseases, psychological profiles). These features lead to abstract categories (e.g., diabetes, influenza, antisocial, extrovert) which, once formed, serve to classify new clients into these categories after they are properly assessed. Subsequently, interventions are designed for each category (e.g., medication, psychological therapy, educational programs), and they are applied individually or collectively to clients who fit into these categories. This approach is firmly established in the medical sciences, where the "product" (for institutions) or the "object" (for science) is health in a biological sense, but it is also well established in certain psychological and social sciences where the "product" is education or personal development and socialization in a social sense. Exemplary of this approach are educational studies that attend to child characteristics and design special programs for those students who are labeled as "different." Intercultural education focused on children's nationalities, special needs focused on disabilities, or educational support for learning difficulties are representative examples of this approach and have been discussed and criticized elsewhere (Bernstein 1986; Coll and Miras 2001; Franzé et al. 1999; Marchesi and Martín 1998).

Within this approach, the causal "agent" of "change" in clients is the treatment (e.g., medication, psychological therapies, educational programs, etc.). Consequently, research tries to achieve two basic things: (a) to establish correlations between the "agent" and the "product" in order 
to estimate how one agent can improve one product; (b) to improve the "agents" when the "product" is not the one expected. In this paradigm, institutions are considered as a "container" in which all these things happen and they are not considered as playing a role in the agency of "agents" or in the quality of "products." In order to improve institutional products, research should improve the agents - in this case, treatments, medicines, psychological therapies, etc.

The second approach stems from the field of evaluation and assessment and has a contextual-ecological underpinning. It developed to solve three limitations attached to the above approach. The first critique has to do with how institutions are conceptualized. In the previous approach, institutions remained a "black box" for researchers and for the community. The second limitation has to do with the "agents." Above we find a narrow and instrumentally defined range of agents. This second approach introduces an ecological perspective which is very useful for finding new unnoticed agents throughout different contexts and not only in factors experimentally controlled under laboratory-like conditions. The third and final limitation has to do with the notion of context. The first approach does not involve any notion of context except when stating the necessity of isolating factors from their social or natural context. This new approach takes into account the fact that a social product may sometimes be attached to contextual particularities. This means that to understand the products of an institution we should look at the context in which that product was built.

However, the general methods employed in the first approach (quasiexperimental or correlational and always within a positivist and hypothetical-deductive frame) are still useful if applied under these new theoretical conditions, i.e., studied inside institutions and other related contexts. To do so, new questionnaires and observational scales were designed to scrutinize relevant factors from inside institutions (observable behavior, school marks, child-educator ratio, family-institution contacts, resources, spaces, funding, management, etc.), relevant related natural contexts (peer groups, school, family) and the relation between these contexts.

In summary, an ecological perspective (a) sees institutions not as black boxes, but as a web of factors branched throughout different contexts; (b) is "naturalistic" in its approach to the construction of products; (c) which leads to a conception of "improvements" based not only on improving "agents," but also on improving the contextual conditions where these agents operate. In the field of formal education, some examples of this approach are those focused on the sociocultural status of children's families, family living conditions, parental beliefs, teacher-child ratios, economic school resources, or teaching styles (OCDE 2007; Palacios 2003). 
In the field of child care in Spain, this is the main approach visible nowadays in many research and policy reports (Bravo and Fernández 2003, 2001; Defensor del Pueblo 1991; Defensor del Pueblo Andaluz 1999; Fernández 1998; Fernández et al. 2003).

The third approach involves theoretical, epistemological, and methodological changes associated with an interpretive approach to social research. This last approach developed in response to the limited conception of the social world implicit in previous approaches. Drawing on a constructionist and sociocultural perspective (Berger and Luckmann 1966; Bruner 1991; Garfinkel 1984), this tradition addresses three issues that have been taken for granted in process-product and ecological-contextual studies: (a) the products in social and welfare institutions are built through social processes by actors who are active agents and guide their actions based on the meanings they construct about their actions; (b) meaning construction and the constraints on action are an ongoing and dynamic process; (c) action and the construction of meaning are culturally, socially, and historically situated; so thick descriptions of the relation between actions, practices, and contexts and the meanings circulating between them are needed (Erickson 1989; Geertz 2000). In other words, a basic tenet of an interpretive perspective is that similar actions do not necessarily imply similar causes, since different actors may attach very different meanings to the same behaviors. In Spain, the incorporation of an interpretive perspective into the study of social and welfare institutions is a quite recent phenomenon. Formal education has received the most attention and several studies scrutinize classroom activities in order to understand how school products are created (Coll and Edwards 1996; Cubero 2001).

\subsection{Social practices in welfare institutions}

Regardless of the paradigm that guides research, most studies focus on "formal practices" (FPs) or even consider these to be the only possible object of study. From our perspective, formal practices are a type of social practice (Wenger 1998) which are planned in great detail by institutional staff, are oriented to institutional goals, and institutions "believe" they are the bricks which build their product. Often, formal practices are evaluated and studied by the institutions themselves and by external researchers. As a result of this assessment, some are deleted and others maintained or improved consciously by the institution in order to produce the best possible products.

Yet an increasing number of studies, often based on ethnographic research, have paid attention to other social practices and institutional con- 
texts (Barton et al. 1999; Lahire 2003). These studies show that institutional products are not constructed only by formal practices but also, and very significantly, by "informal practices" (IPs). From our perspective, the features of these practices are basically the opposite of "formal practices": they are not planned by the institution, they are not oriented toward institutional goals, they are not seen as important or as bricks that build products, they are excluded from evaluation and are often thought of as "invisible practices" (not perceived consciously as social practices by agents) or "hidden practices" (when these practices are perceived as such by them, but are hidden from other agents). In institutions where the product is personal development and socialization, the role played by informal practices may be especially relevant. If personal development and socialization are achieved through social interaction, any social interaction potentially plays a role in these processes (Schieffelin and Ochs 1986).

Taking this discussion as a starting point, in this paper we argue that a careful focus on social practices as constituting institutional products must be taken into consideration. We develop our argument in two strands. First, we highlight the diversity and complexity of institutional social practices and develop a conceptual framework designed to understand institutional functioning based on the flows and trajectories of the constituent social practices. Second, we outline the methodological requirements that stem from this framework and outline how linguistic ethnography may meet these challenges. Our analysis draws on the results of a small ethnographic study in two residential child care institutions (RCCIs) in central Spain that is described in the following section.

\section{Method}

Our discussion draws on an ethnography carried out in one kind of "social and welfare institution": residential child care institutions. In Spain, these spaces are mainly comprised of flats and houses in which a group of six to ten children live under the care of a group of social educators. These children live there because they are under state protection, that is, they have been removed from their families by public authorities once it had been considered their families were playing a negative role in the child's development and socialization.

In Spain, RCCIs might be considered as an evolution of orphanages. Orphanages covered an important social necessity: taking care of children with no means to support their needs. In 1996, the law regarding such institutions changed, and this resulted in some key guidelines for improving 
the child protection system: (a) two different and separated pathways were established, one for children in need and another for "delinquent minors"; (b) large institutions outside the city limits were replaced in favor of family-like houses placed within the locality; (c) professionals were designated as the primary caretakers of children in the system, in contrast to vocational and/or religious volunteers; ${ }^{1}$ (d) "normalization" was established as the cornerstone principle to design interventions. From 1996 onwards, this policy, aimed at creating a modern and professional child protection system, has been complemented with a public funding policy in which the "externalization" of management of those institutions is the dominant scheme to the extent that, currently, in some areas of Spain nearly $100 \%$ of RCCIs are under the management of private organizations or NGOs - a tendency that can be observed in Spain and in other parts of Europe.

In this context, the first author of this paper spent five months (between April and August 2005) doing participant observation in two different but related residential institutions: a house and a flat located in the same city and run by the same non-governmental organization. The research focus was on processes and practices contributing to changes in the personal development and social integration of children in these residential contexts. In doing so, many social practices and activity contexts were documented but, eventually, observations were focused on computer-mediated communications (CMCs) due to their particular relevance in children's everyday lives in terms of presence, time, and meaningfulness. CMCs were primarily represented by conversations in Internet chat rooms between children in care and other users. These conversations were documented initially through field notes and in the final stages of fieldwork they were recorded (with children's permission) using special software.

Other practices were also observed. Access to the practices discussed in later sections was negotiated informally with the participants during the fieldwork. Thus, children gave the researcher access to some practices from which other adults in the institution were excluded. Nonetheless, the relationship with the children became a continuously ongoing process in which access privileges were gained and lost as a result of the researcher's conflicts and confidences with the children (cf. Emond 2005). These dynamics were intertwined with the different roles and relationships the author had with the children, first as an employee of the institution and later exclusively as a researcher.

In the following sections, we show the diversity of social practices that take place within social and welfare institutions by focusing on the analysis of one RCCI in Spain. Among the different kinds of practices identified and categorized by the researchers, there is a type, which we call 
"paradoxical practices," that characterizes these institutions. Continuing with this identification, we discuss what a paradoxical institution may be in relating this definition to RCCIs. Later, we analyze the trajectory of one of these paradoxical practices, addressing the changes throughout its conception to its implementation. The nature of the changes observed and some of their consequences are discussed in order to argue for a more complex framework for assessing and researching social and welfare institutions.

\section{Social and welfare institutions from an approach focusing on social practices: some empirical evidence}

\subsection{The diversity of practices within a "paradoxical institution"}

In RCCIs we found expectable social practices such as formal practices (FPs) and informal practices (IPs). Furthermore, we also found other kind of practices which we will call paradoxical practices (PPs). The following examples illustrate the similarities and differences between these three kinds of practices.

Within the RCCIs we studied, we found FPs such as "English teaching." A specialized teacher went to the houses at a certain time of the day to instruct the children at an elementary school level of English language. In these tutorial classes they used special materials such as exercises from an English book or computer software. The activities were previously programmed by the teacher-although with a certain degree of flexibility. We will not go in depth into FP since they are well known.

There were also IPs such as "children playing video games with educators," which took place as an improvised activity proposed by children during their free time.

(1) Field notes (day 10)

... (6:00 pm) In the evening I went into the living room and saw JF (educator) watching TV or listening to music with the children. I asked him whether he had brought his Play Station or not. He told me that perhaps he would go home later to pick it up if we wanted to. ... (8:30 pm) (Gimena, Silvia and I) went back to the flat and we stayed there. When we arrived, the children had not had their dinner yet, and JF (educator) was playing a football game called FIFA 2004 with Juan, Roberto and Pedro on the Play Station. I waited for my turn because I wanted to play as well, and after a while I played a game with Pedro. Most of the time it was a draw but at the end he scored. 
The decision to engage in such activities was not related to explicit institutional goals and was not part of institutional work plans. Their unfolding was related to simple fun by all participants in that space and time and the decision to engage in video game playing was made at the same moment in the activity without any reference to institutional planning. But in these homes, there were also activities that appeared to be informally organized, but yet, being supported by the institution's plans-in other words PPs.

For example: "educators helping children do their homework." This support consisted of children completing their homework after lunchtime in their rooms and asking educators to help them when necessary. This activity appeared as very family-like in the sense that educators tried to help the children in the way (middle-class) parents would help their offspring and they were not construed by participants as similar to the English lessons described above. It seemed to be an activity that simply happened, not as a part of institutional work schedule. Yet there was institutional planning behind this activity. The organization situated this activity in a specific time slot and increased the number of educators present in the homes during homework time. Educators were very conscious about their roles and tasks in this activity and they urged children to engage in the routines of the activity such as taking their seats to begin their homework.

(2) Field notes (day 3)

... (4:05 pm) Sofia (educator) arrives at the flat with Juan (she picks him up at the bus station at 4:00 pm) and, as she comes into the living room, all the children automatically begin to organize the room and afterwards they go to do their homework. In the evenings there are two educators. One of them is JF, who stays in the flat from Monday to Friday. He arrives at 2:00 pm after picking up Luis from school. He stays in the flat until 10:00 pm when another educator arrives to stay at night. The second educator begins his work at 4:00 pm in the evenings when he picks up Juan from the bus that brings him home from his school for students with special needs. The second educator stays at home less time than JF and, although I need to confirm this, his role seems to be specifically to help during homework time.

Paradoxical practices like this are characteristic of RCCIs because these institutions are often involved in social practices aimed at designing artificially informal environments, which are created by highly formalized processes. This is why we call such institutions "paradoxical institutions." To understand better the paradoxical nature of RCCIs (and eventually 
that of other paradoxical institutions) we may compare them with schools. School is a formal educational institution per excellence. Its central activities can be classified through what we called "formal practices." The purpose of school is to offer formal instruction in order to reach institutional and academic goals. In RCCIs things work differently. Some of the broader goals are quite similar (contributing to socialization and personal development), but the ways in which they are reached are quite different. While schools build highly formalized environments to carry out their activities, RCCIs work hard to artificially build a highly informal environment to accomplish their work. Life in RCCIs should be closer to family life (considered as very informal) than to school life (highly formalized). This difference is the result of ideological and social policy changes in recent years, both in international and Spanish children's social policies (Palacios 1997). Through an established "principle of normalization" implemented in the field of children under state care, RCCIs are expected to artificially create family-like environments in single homes or flats, with a reduced group of children, who should be encouraged to use local public resources and interact with their own non-institutionalized friendships and networks.

To summarize, there are some differences and similarities in the institutional planning and unfolding of formal, informal, and paradoxical practices. PPs and FPs are similar in their features (they are planned, oriented, and assessed within institutional goals) but different in their appearances (PPs are not carried out in special places, with special material or formalized resources). PPs and IPs are similar in their appearance but are different in their features. These oppositions complete the matrix of formal and informal practices and arrangements conceptualized by the institution, but this does not exclude the possibility that actors (especially children) in the institution engaged in practices that complicated these oppositions.

\subsection{Genealogy and construction of a social practice: a paradigmatic case}

Our aim here is to examine how institutional goals are achieved and how research and assessment manage to track those achievements. The analysis in the previous section demonstrates that several types of social practices cohabit within social and welfare institutions and that PPs are the emblematic social practice within paradoxical institutions. In this section we pay attention to the genealogy of a particular PP as an analytical case. The examination of this case underscores the methodological implications we want to develop.

As explained in the method section, a frequent practice during field work involved children chatting with other people through the Internet. 
This happened very often in the flat (where they had a computer connected to the Internet) and in different places throughout the city as well. Initially, this practice appeared to be very informal in its planning. Children established private conversations in a public chat room or through Messenger software and talked about anything they wanted to. There was very little control by adults and educators did not read their conversations.

Nonetheless, computer use as a social practice did not take place in children's lives as something casual or non-planned by the institution. Rather, there was significant institutional work behind it. The organization had established as one of its goals the development of children's skills in the use of information and communication technologies (ICT). To reach this goal, the following measures were implemented: send the older children to out-of-school computer classes (to learn how to use messaging software, e-mail, Internet, text and image processing software, etc.), provide each flat with a computer connected to the Internet, provide educators and children with special educational software to work with, facilitate children's access to other settings where they could use computers in their free time (such as a city-center play center associated with the organization) and, finally, introduce computers into the "reward-punishment" dynamics of the homes by restricting computer use when children behaved improperly. In other words, children chatting through the Internet would appear to be a PP in which significant institutional work was invested to produce an "artificial" informal practice. Children were expected to use computers for their homework and school assignments and also in their leisure time. In this context, through special software and explicit rules on the part of educators, access to pornographic and violent content was prohibited.

Yet, during field work we observed children doing many other things with computers such as listening to music, playing games, randomly surfing the Internet, downloading images, watching films, or chatting in public chat rooms. For the oldest girls, the main activity was chatting, and for the younger boys, the main activity was playing computer games. In fact, we never documented instances of children using the text processor, the educational software, or using computers for their homework. Further, children were able to access sexual and violent content through strategies such as accessing Web sites where the protection software did not work, when educators or other children were not present, by playing adult games that worked even with the protection software switched on, or chatting with other people about sex and other "banned topics" when no one "untrustworthy" was present. The following conversation exemplifies one of these sub-rosa practices: 
(3) Field notes and Messenger conversation-each number represents a "turn" in the chat window (day 8)

(3:50 pm) Angel begins an argument through msn with a friend of Ismael, who we saw this morning and with whom Angel had a fight recently, which is why he did not spend the morning with Ismael and his group of friends. They are arranging to meet and fight. Jesus M. tells Angel that he is already in trouble because the other kid, whose nickname is calavera 'skull', is an anarchist_-given the icon he has in the msn window and the way he talks. Angel manages to ignore these threats by praising the icons that he receives through the messenger conversation.

1 (Angel): Te aviso que no le toquen que soy capaz de ir a tu casa a buscarte y si no estás le doy un ostión a tu hermano I'm telling you don't touch him because I will go to your house and if you are not there I will "beat the shit" out of your brother

3 (Skull): Sólo le tocan si se lo digo yo They only touch him if I say so

4 (Angel): Tú díselo y te cagas te lo digo yo Say so and I you'll be "fucked"

Si se que vas a los Gárate soy capaz de ir a la salida el lunes

I know you go to Gárate and I am capable of going on Monday and waiting (for you) at the (school) exit

6 (Skull): Sabes a qué hora salgo

Do you know at what time I get out

7 (Angel): A la 1 y media o dos tengo un amigo que está estudiando ahi

At half past 1 or two I have a friend that studies there

8 (Skull): Cómo se llama

What's his name

A qué curso va

What grade is he in

10 (Angel): Jajajajajajajajajajajajaaj

11 (Skull): Dímelo no te cagues por decírmelo

Tell me don't "shit your pants" for telling me

12 (Angel): No respondo a esas preguntas pardillo de mierda

I don't answer those questions you "full of shit fool"

13 (Skull): Dime cómo se llama

Tell me his name 
This segment took place after Angel (resident of the home) and Skull, according to Angel, had a "real" fight in the street-incidentally, Angel also reminded the first author that he had met Skull during a fieldwork session at a park with Angel and his friends. As shown in the conversation, Angel establishes interactions with peers from outside the institution. However, in this case the relationship is completely antagonistic and shows Angel outlining possible violent actions (lines 1, 3, and 4) that the educators within the residential home would not endorse- these actions, in fact, resemble the type of unsupervised behaviors that, typically, workers from social services consider indicators of social risk and mobilize the procedures that may eventually put a minor under state protection. When engaged in practices and conversations of this type, children were not involved in the activities designed for the development of computer skills or other institutional goals. Educators more or less knew that children mainly used computers to chat and play but this seemed to be tolerated because, from their perspective, measures had been taken to protect children from certain developmentally inappropriate content. But in light of example (3), we see that certain practices, in this case a paradoxical practice, seem to be constructing at the same time a rather different product than the one planned by the institution and that the organization is unaware of this change. This example is extremely relevant if we take into account that, as we said above, PPs are the principal working tool of paradoxical institutions such as RCCIs. From a policy-making perspective, policies based on "normalization" that do not take into consideration or underestimate paradoxical practices seem to be failing in understanding how those institutions contribute to broader social goals.

We have analyzed one prototypical practice of paradoxical institutions. This transformation raises a number of questions. The first set has to do with the conditions that allow for certain practices to be transformed and appropriated by children in directions that are very different from those intended by the organization. In light of the informal and paradoxical nature of some practices, the second problem has to do with how institutionality is defined in itself. In the following section we propose a framework that may help to begin addressing these issues.

\section{A framework to approach social and welfare institutions}

\subsection{Theoretical foundations}

The distinctions of formal, informal, and paradoxical practices are not meant to constitute an exhaustive set of closed categories - it is possible 
that many others could be documented and postulated. They work as a set of lenses that allows us to elaborate a wider conception of how institutions "construct their products." These can be organized into a framework in which practices are placed along a set of dimensions or planes of action where different levels of "institutional reality" unfold. Arguably, there are multiple levels of action (dimensions) but for our purposes it is sufficient to focus on two: a planning dimension and a practical dimension.

The planning dimension refers to the reflexive and ideological level at which institutions develop their planning work. In this dimension, the institution makes predictions on how it will work (or would like to work) in the future. Often, this involves constructing certain formalized discourses in which professional and academic knowledge, experiential knowledge from the institution's own history, and agent's everyday conceptions form the building blocks. As discourse and forms of knowledge they can be documented and examined.

The practical dimension refers to the implementation of the designed activities, but these co-exist with other kinds of activities or practices that, while not planned, take place within institutional life and contribute in some way to the construction of institutional products (desired or not). Within this practical dimension we postulated, we found what we defined as formal, paradoxical, and informal practices in the residential child care institution we studied.

The planning dimension and the practical dimension are each composed of several social practices; these are aimed at planning institutional functioning in the planning dimension, and at implementing the designed plan in the practical dimension (along with non-planned practices such as IPs). The key question is to understand how this process unfolds as the result of interrelationships between the planning and the practical dimensions because while some practices follow foreseen paths, others do not. Formal and paradoxical practices take place within the practical dimension of the institution as they have been carefully planned within the planning dimension. To understand formal and paradoxical practices ethnographically, we need to also attend to planning practices in the planning dimension (not only, but mainly). However, if we wish to understand why and how informal practices take place in an institution, the planning dimension does not play the same role, since informal practices are not planned and even may be hidden from institutional agents. Finally, to understand those practices that change dramatically when carried out (such as the PPs analyzed in Section 4), we need to attend to both the planning and the practical dimensions, since they involved work designed to become one type of practice (PP) but unfold in unexpected ways. Thus, we will need to contemplate potential mediating factors that 
are involved in this transformation. In other words, we can postulate an intermediate dimension, which we call interlude, in which these transformations take place. What we are describing as interlude is often captured in one of the multiple notions of context (Duranti and Goodwin 1992; Blommaert 2005) that are used in sociolinguistics but which puts a stronger emphasis on the diachronic element that relates planning with practical implementation. Interactional and observational analysis of unfolding social practices and discourse permits one to document and disentangle divergences between expected and actual outcomes and processes and, often, allows one to define context as a synchronically emergent component of discourse which may have a role in explaining these divergences. However, by postulating an interlude as an analytical dimension, we consider that it is also relevant (and possible) to document the policybureaucratic, social, institutional, and individual conditionings that help explain why certain planned outcomes are transformed or not or why they are transformed in particular directions (and others not). In our framework, the interlude in the particular case of residential child care institutions captures especially the ideological conditions that determine children's processes of appropriation of a variety of social elements in their non-regulated practices.

To recapitulate, so far we have (a) argued in favor of studying diverse social practices within institutions, particularly those similar to residential child care institutions; and (b) presented data to support a model that articulates these practices. Within this argument, the final point to be made is a methodological one. In the following section we outline the role that linguistic ethnography could play in this framework.

\subsection{Linguistic ethnography: a methodology to study paradoxical social institutions}

The model we have presented requires a research approach that is capable of: (a) exploring many agents acting in conjunction; (b) studying the agents in their different natural contexts; (c) examining participants' (agents and clients) perspectives and meanings; (d) documenting participants' interactions as dynamic processes embedded in social practices; (e) locating these social practices in the complex schemes that guide institutional life; (f) considering the relationship between everyday life and macro-social processes.

Linguistic ethnography, as discussed in the introduction and the other papers of this special issue and elsewhere (Rampton 2007; UKLEF 2004; Creese 2008), potentially meets several, if not all, of these requirements. In its programmatic calls it highlights the importance of subjectivity and 
meaning and the relevance of context for the interpretation of social (and institutional) life. These aspects have to do with what Shweder (1996) calls qualia research objects, since their comprehension depends mainly on human subjectivity, while arguing that qualitative methods such as ethnography are the most suitable to these research objects. But not only ethnography has been addressing the problems of meaning and subjectivity. In psychology, sociology, and linguistics, a variety of approaches generally associated with the linguistic turn (Rorty 1967) or the cognitive revolution (Bruner 1991) have encouraged researchers to focus on meaning and language. Within linguistics this has moved analysis in line with a view in which "meaning is far more than just the 'expression of ideas', and biography, identifications, stance and nuance are extensively signaled in the linguistic and textual fine-grain" (Rampton 2007: 585). This premise in linguistic ethnography is shared by and draws from traditions such as conversation analysis (Sacks et al. 1974; Schegloff 2007), interactional sociolinguistics (Gumperz 2001), and even aspects of critical discourse analysis (Fairclough 1995).

Ethnography, especially defined through reflexivity (Hammersley and Atkinson 2005), allows ethnographers to change their focus within the field and, more relevantly, to find new practices and problems to study during the research process. This allows unexpected processes and factors to come to the foreground, as has been the case in our study when we uncovered informal and sub-rosa computer use practices. Due to that flexibility and to the construction of the relationship with participants, we have been able to access places and to share practices that were not noticed or shared by other adults but where, nevertheless, institutional products were being constructed. In this sense, as is always the case in ethnographic research, the relationship with participants was a key aspect of defining fieldwork and access to particular social spaces. In our case, the renegotiation of roles between the researcher and the children in the institution, along with the construction of trust with children, gave us access to their chat room conversations and thus allowed us to uncover and define paradoxical practices - and develop a framework in which dimensions that are not directly observable (e.g., interlude) can be formulated and conceptualized and accounted for methodologically. Traditional research in institutions of the type that was presented in the introduction is incapable of doing this.

As a linguistic ethnographic project, the study is not at a stage where in-depth analysis of linguistic data has come to the foreground, but its theoretical concerns have pointed out the type of data that can and should be documented and analyzed (e.g., chat room conversations, team meetings, the production and interpretation of institutional 
documents, etc.). Apart from this more micro-analytical work, linguistic ethnography also has resources to study the "flow" of practices and discourses which, according to our model, are moving conceptually from one dimension to the other. Following the history of practices and discourses from the planning to the practical stage allows us to document changes in the discourses circulating from the one to the other-which we have located in the interlude. Here, incorporating concepts such as the "natural history of discourse" (Silverstein and Urban 1996) or "entextualization" (Bauman and Briggs 1990) may be very useful, given their emphasis on the changes in discourse and practice during the different occasions in which it is de-contextualized and re-contextualized.

Finally, the model we have presented and the discussion of contextual factors that play a role in transforming social practices is illustrative of the position of linguistic ethnography in relation to macro-micro oppositions (UKLEF 2004). On the one hand, through detailed analysis of interaction, it "ties down" social analysis and attributes a constitutive role to daily interactions. On the other hand, it simultaneously considers that linguistic analysis should be "opened up" and acknowledges the role of social processes or contextual factors far removed in time and space from the actual practices under scrutiny (Blommaert 2005).

\section{Conclusions}

In this paper we discussed several problems. First, we have argued in favor of linguistic ethnography as an approach used to examine some of the social complexities that unfold in institutions such as residential child care institutions, which given their objectives and organization produce certain forms of paradoxical practices. This approach is underdeveloped in relation to other research and assessment traditions in the field of social and welfare programs and institutions, and this paper is a first step in redressing this imbalance. Second, especially in contexts such as RCCIs, we have shown how important it is to focus on social practices as dynamic processes instead of sets of predefined factors and variables. Furthermore, in our argument in relation to the interlude as an intervening dimension, we have shown how these dynamic processes are understandable both as a result of the immediate contingencies of activity and of interrelationships between different actors and dimensions involved in the organization of the institution and institutional life. These interrelations can be tracked and documented and should be incorporated into the final interpretation of institutional processes. Finally, the existence of dramatic changes in planned paradoxical practices raises key questions for RCCIs: how can 
PPs be institutionally evaluated? We have shown how some PPs completely change to the extent that in their practical realization they result in the construction of products (development, socialization, skills) which are potentially not desired by the institution. One possibility is to raise the institution's awareness of this unforeseen practical implementation and increase institutional and organizational monitoring between what is planned and what is implemented. Yet, while this may be incorporated as an institutional expectation, it is perhaps impossible to realize completely given RCCIs' apparently paradoxical commitment to formally designing domestic informal settings and the reality that in these institutions there will always be space for the unplanned and informal.

This paper highlights some practices within an institution. This does mean that other institutions, whether they are paradoxical or not, whether they are highly organized (such as schools) or less organized (such as family), lack these practices. We admit that paradoxical practices may appear in schools and in families, and the same goes for formal and informal practices. The aim of this paper is not to compare these settings but to uncover and understand complex institutional processes within social and welfare institutions, and, among others, one of the discoveries made is that paradoxical practices are central in RCCIs.

More generally our analysis of practices in RCCIs attempts to establish a dialogue between linguistic ethnography, which is a powerful theoretical and methodological approach to uncover the social within discursive detail, on the one hand, and a conceptual theorization of this institutional space, on the other hand. These are interrelated concerns that may allow us to place different works along a continuum between detailed ethnographic discourse analysis and the social theorization of institutionality. Admittedly, our paper is closer to a general conceptualization of certain institutions designed for children than an empirical analysis of discursive practices in these settings. Yet, this positioning illustrates one of several configurations within linguistic ethnographic analyses of institutions as exemplified in this special issue.

\section{Notes}

* We would like to thank Peter Flynn, Chris Hall, and Ben Rampton for their detailed comments to previous versions of this paper. We would also like to thank the participants in the Research Workshop on Language and Literacy at King's College London who commented and provided feedback to an early presentation of the ideas in this paper. Finally, we would like thank the three anonymous reviewers of Text \& Talk for their detailed feedback. 
1. In Spain, professionals in residential child care institutions - which in this country involves university-level training in some educational/social science — are known as "educators" since their natural university degree is called "Social Education." In other European countries, the literature refers to them as "carers," "care-takers," or "social pedagogues."

\section{References}

Barton, David, Mary Hamilton \& Roz Ivanic. 1999. Situated literacies: Reading and writing in context. London: Routledge.

Bauman, Richard \& Charles Briggs. 1990. Poetics and performance as critical perspectives on language and social life. Annual Review of Anthropology 19. 59-88.

Berger, Peter \& Thomas Luckmann. 1966. The social construction of reality. Garden City, NY: Doubleday.

Bernstein, Basil. 1986. Una crítica de la educación compensatoria. In C. Wright Mills (ed.), Materiales de sociología crítica, 203-218. Madrid: La Piqueta.

Blommaert, Jan. 2005. Discourse. Cambridge: Cambridge University Press.

Bravo, Amaia \& Jorge Fernández. 2001. Evaluación de la integración social en acogimiento residencial. Psicothema 13(2). 197-204.

Bravo, Amaia \& Jorge Fernández. 2003. Las redes de apoyo social de los adolescentes acogidos en residencias de protección. Un análisis comparativo con población normativa. Psicothema 15(1). 136-142.

Bruner, Jerome. 1991. Actos de significado. Madrid: Alianza.

Coll, Cesar \& Derek Edwards. 1996. Enseñanza, aprendizaje y discurso en el aula: Aproximaciones al estudio del discurso educacional. Madrid: Fundación Infancia y Aprendizaje.

Coll, César \& Mariana Miras. 2001. Diferencias individuales y atención a la diversidad en el aprendizaje escolar. In César Coll, Jesús Palacios \& Álvaro Marchesi (eds.), Desarrollo psicológico y educación, vol. 2: Psicología de la educación escolar, 331-353. Madrid: Alianza.

Creese, Angela. 2008. Linguistic ethnography. In Kendall King \& Nancy Hornberger (eds.), Encyclopedia of language and education (2nd edition). Volume 10: Research methods in language and education, 229-241. Berlin: Springer.

Cubero, Rosario. 2001. Maestros y alumnos conversando: el encuentro de las voces distantes. Investigación en la escuela 45. 7-19.

Defensor del Pueblo. 1991. Estudio sobre la situación del menor en centros asistenciales y de internamiento y recomendaciones sobre el ejercicio de las funciones protectora y reformadora. Madrid: Publicaciones de la Oficina del Defensor del Pueblo.

Defensor del Pueblo Andaluz. 1999. El sistema de protección de menores. Sevilla: Defensor del Pueblo Andaluz.

Duranti, Alessandro \& Charles Goodwin (eds.). 1992. Rethinking context: Language as an interactive phenomenon. New York: Cambridge University Press.

Emond, Ruth. 2005. Ethnographic research methods with children and young people. In Sheila Greene \& Diane Hogan (eds.), Researching children's experience, 123-139. London: Sage.

Erickson, Frederick. 1989. Métodos cualitativos de investigación sobre la enseñanza. In Merlin Wittrock (ed.), La investigación de la enseñanza, vol. 2. 195-301. Madrid: PaidósMEC.

Fairclough, Norman. 1995. Critical discourse analysis. London: Longman. 
Fernández, Jorge. 1998. Manual de programación y evaluación para los centros de protección a la infancia. Salamanca: Junta de Comunidades de Castilla y León.

Fernández, Jorge, Elvira Álvarez \& Amaia Bravo. 2003. Evaluación de resultados a largo plazo en acogimiento residencial de protección a la infancia. Infancia y Aprendizaje 26(2). 235-250.

Franzé, Adela, Lorenzo Casellas \& Carmen Gregorio. 1999. Intervención social con población inmigrante: Peculiaridades y dilemas. Migraciones 5. 25-54.

Garfinkel, Harold. 1984. Studies in ethnomethodology. Malden, MA: Blackwell.

Geertz, Clifford. 2000. La interpretación de las culturas. Barcelona: Gedisa.

Gumperz, John. 2001. Interactional sociolinguistics: A personal perspective. In Deborah Schiffrin, Deborah Tannen \& Heidi Hamilton (eds.), The handbook of discourse analysis, 215-228. Oxford: Blackwell.

Hammersley, Martyn \& Paul Atkinson. 2005. Etnografia: Métodos de investigación. Barcelona: Paidós.

Lahire, Bernard. 2003. Los orígenes de la desigualdad escolar. In Álavaro Marchesi \& Carlos Hernández (eds.), El fracaso escolar: Una perspectiva internacional, 61-71. Madrid: Alianza.

Marchesi, Álavaro \& Elena Martín. 1998. Calidad de la enseñanza en tiempos de cambio. Madrid: Alianza.

OCDE. 2007. PISA 2006 Science competencies for tomorrow's world. Paris: OCDE.

Palacios, Jesús. 1997. Menores marginados: Perspectiva histórica de su educación e integración social. Madrid: CCS.

Palacios, Jesús. 2003. Relaciones familia-escuela: Diferencias de estatus y fracaso escolar. In Álvaro Marchesi \& Carlos Hernández (eds.), El fracaso escolar: Una perspectiva internacional, 89-98. Madrid: Alianza.

Rampton, Ben. 2007. Neo-Hymesian linguistic ethnography in the United Kingdom. Journal of Sociolinguistics 11(5). 584-607.

Rorty, Richard. 1967. The linguistic turn. Chicago: University of Chicago Press.

Sacks, Harvey, Emmanuel Schegloff \& Gail Jefferson. 1974. A simplest systematics for the organization of turn-taking conversation. Language 30. 696-735.

Schegloff, Emmanuel. 2007. Sequence organization in interaction. Cambridge: Cambridge University Press.

Schieffelin, Bambi \& E. Elinor Ochs. 1986. Language socialization. Annual Review of Anthropology 16. 163-191.

Shweder, Richard. 1996. Quanta and qualia: What is the "object" of ethnographic method? In Richard Jessor, Anne Colby \& Richard Shweder (eds.), Ethnography and human development: Context and meaning in social inquiry, 175-182. Chicago: University of Chicago Press.

Silverstein, Michael \& Greg Urban. 1996. The natural history of discourse. In Michael Silverstein \& Greg Urban (eds.), Natural histories of discourse, 1-20. Chicago: University of Chicago Press.

UKLEF. 2004. UK linguistic ethnography: A discussion paper. http://www.ling-ethnog.org. uk/documents/discussion_paper_jan_05.pdf.

Wenger, Etienne. 1998. Communities of practice: Learning, meaning and identity. Cambridge: Cambridge University Press.

Manuel Palomares is Research Fellow at the Social Policy Research Unit in the University of York. His research interests are qualitative research methods and epistemology, children in the social welfare system, and literacy. His current research focuses on children's socialization in residential child care institutions. Address for correspondence: Social Policy 


\section{Manuel Palomares and David Poveda}

Research Unit, Alcuin College B Block, University of York, York YO10 5DD, England $\langle$ mp703@york.ac.uk〉.

David Poveda is Professor in the Department of Developmental and Educational Psychology of the Autonomous University of Madrid. His research interests are literacy, children's language practices, socialization across different developmental contexts, and social diversity in education. Address for correspondence: David Poveda, Departamento Interfacultativo de Psicología Evolutiva y de la Educación, Facultad de Psicología, Campus de Cantoblanco, 28049 Madrid, Spain〈david.poveda@uam.es〉. 